\title{
Pro-Neuregulin-3, Membrane-Bound Isoform
}

National Cancer Institute

\section{Source}

National Cancer Institute. Pro-Neuregulin-3, Membrane-Bound Isoform. NCI Thesaurus.

Code C118418.

Pro-neuregulin-3, membrane-bound isoform (720 aa, $78 \mathrm{kDa}$ ) is encoded by the human NRG3 gene. This protein plays a role in signaling. 